\title{
Appraisals of Bangladeshi Medicinal Plants Used by Folk Medicine Practitioners in the Prevention and Management of Malignant Neoplastic Diseases
}

\author{
Md. Nur Kabidul Azam, ${ }^{1}$ Md. Mizanur Rahman, ${ }^{1}$ Samanta Biswas, ${ }^{2}$ and Md. Nasir Ahmed \\ ${ }^{1}$ Ethnobotany \& Ethnomedicine Division, TechB Herbal Solution, Kushtia 7040, Bangladesh \\ ${ }^{2}$ Medical College for Women \& Hospital (MCW\&H), Uttara Model Town, Dhaka 1230, Bangladesh \\ Correspondence should be addressed to Md. Nasir Ahmed; nasir.ahmedbd@hotmail.com
}

Received 21 September 2015; Revised 1 December 2015; Accepted 20 December 2015

Academic Editor: Johnson Stanslas

Copyright ( 2016 Md. Nur Kabidul Azam et al. This is an open access article distributed under the Creative Commons Attribution License, which permits unrestricted use, distribution, and reproduction in any medium, provided the original work is properly cited.

\begin{abstract}
Cancer is a group of diseases which is categorized to differentiate into diverse cell types and move around in the body to sites of organogenesis that is key to the process of tumor genesis. All types of cancer fall into the group of malignant neoplastic diseases. In Bangladesh, cancer is now one of the foremost killer diseases and its personal, social, and economic bearing are huge. Plantderived natural compounds (vincristine, vinblastine, etoposide, paclitaxel, camptothecin, topotecan, and irinotecan) are useful for the treatment of cancer. Since there is no extensive ethnobotanical research study in Bangladesh regarding the traditional uses of medicinal plants against neoplasms, therefore, a randomized ethnopharmacological surveys were carried out in 3 districts of Bangladesh to learn more about the usage of anticancer medicinal plants and their chemical constituents having antineoplastic activity. Comprehensive interviews were conducted to the folk medicine practitioners and medicinal plants as pointed out by them were photographed, collected, deposited, and identified at the Bangladesh National Herbarium. The various plant parts have been used by the healers which included whole plant, leaves, fruits, barks, roots, and seeds. This study evaluated considerable potential for discovery of novel compounds with less side effects in the management and prevention of malignancy in cancer.
\end{abstract}

\section{Introduction}

Cancer is defined as an abnormal growth of cells caused by multiple changes in gene expression leading to deregulated balance of cell proliferation and cell death. Cancer is those tumors [1] that have developed the ability to invade the surrounding normal tissues. Cancers are caused by exogenous chemical, physical, or biological carcinogens in humans and the mechanisms of carcinogenesis are often multifactorial and complex. Different factors may act by different mechanisms and at different stages of tumor development [2]. A cancerous cell is traveling throughout the body using the blood or lymph systems, destroying healthy tissue in a process called invasion, and that cell manages to make new blood vessels to feed itself in a process called angiogenesis. Tumors may activate angiogenic inhibitors (angiostatin and endostatin) that can modulate angiogenesis at both the primary site and downstream sites of metastasis [3, 4], when a tumor successfully spreads to other parts of the body using the blood or lymph systems known as metastasis.

Cancer is a leading cause of death in the western world. In the United States and a number of European countries, cancer is the second leading destroyer after cardiovascular diseases [5]. Cancer can occur at any age and the average age at the time of diagnosis for cancer is 67 years, and about $76 \%$ of all cancers are diagnosed at the age of 55 or older. Although cancer is relatively rare in children, it is the second leading cause of death in children ages of 1-14. In this age, leukemia is the most common cause of death. The overall death rates due to cancer have almost tripled since 1930 for men and gone up over 50\% for women [6]. World Health Organization (WHO) estimates that some 84 million people will die of cancer between 2005 and 2015 around the world. In 2007, there were 7.9 million deaths from cancer, around 13 percent of all deaths. 
1.1. Cancer Epidemiology in Bangladesh. The National Institute of Cancer Research and Hospital (NICRH) started a cancer registry in 2005 for the first time in Bangladesh along with the World Health Organization (WHO). This report covers three years from 2005 to 2007. Data were collected from 24,847 cancer patients who appeared in the NICRH for the first time [7]. Among them, 10,847 (57.6\%) were males. Lung cancer was the leading cancer (17.3\%), followed by cancers of breast (12.3\%), lymph nodes and lymphatics $(8.4 \%)$, and cervix $(8.4 \%)$ for sexes combined in all ages. In males' lung (25.5\%) and in females breast (25.6\%) and cervical $(21.5 \%)$ cancers were predominant. In children aged 14 years or younger, lymphoma, retinoblastoma, osteosarcoma, leukemia, and kidney cancers were most prevalent. Lung cancer in males and cervical and breast cancer in females constitute $38 \%$ of all cancers in Bangladesh [7]. According to the WHO data published in April 2011, oral cancer deaths in Bangladesh reached 11,562 or $1.21 \%$ of total deaths. The age adjusted death rate is 12.52 per 100,000 of population ranking Bangladesh 4 in the world. There are more than one million (10 lakh) cancer patients in Bangladesh while approximately 200,000 new patients, mostly women, are added every year creating a social burden on the country $[8,9]$.

Various plants have been used against cancer and tumor in traditional medicine system of Bangladesh since many years. Traditional medicinal knowledge has been a means towards the discovery of many modern medicines [10]. Traditional medicine is practiced in Bangladesh by folk medicine practitioners, also known as Kabirajes who utilize various formulations of medicinal plants in most of their preparations. We have observed that the Kabirajes of various districts and areas use diverse varieties of plants for the treatment of schizophrenia and psychotic problems [11], cardiovascular problems [12], eye infections [13], snakebite [14], diabetes [15], gastrointestinal disorders [16, 17], HIV/AIDS related infections [18], rheumatoid arthritis [19], cattle diseases [20], and so on.

It was objective of the present study to conduct a randomized ethnopharmacological survey to learn more about the medicinal plants used by folk medicine practitioners of Bangladesh for the treatment of cancer and also to do comprehensive study on several published articles attributed to the in vivo or in vitro anticancer properties of these species. The anticipation was that the medicinal plants used by the Kabirajes can prove to be a useful source for further scientific studies leading to discovering more efficacious antineoplastic drugs.

\section{Methodology}

2.1. Geographical Location of the Survey Area. The present randomized surveys were carried out between October 2013 and March 2014, among the Kabirajes of three districts of Bangladesh, namely, Jessore, Khulna, and Narail. Jessore district geographically is in the southwestern region of Bangladesh. It is located at $23^{\circ} 10^{\prime} 0^{\prime \prime}$ North, $89^{\circ} 13^{\prime} 0^{\prime \prime}$ East, bordered by Khulna and Satkhira district to the south, India to the west, Magura and Narail district to the east, and Jhenaidah district to the north. Khulna and Narail district geographically coordinate at $22^{\circ} 48^{\prime} 0^{\prime \prime}$ North, $89^{\circ} 33^{\prime} 0^{\prime \prime}$ and $23^{\circ} 10^{\prime} 0^{\prime \prime}$ North, $89^{\circ} 30^{\prime} 0^{\prime \prime}$ East, respectively. These three districts (Figure 1) are a part of Khulna division.

The surveys were conducted with the help of a semistructured questionnaire and the guided field-walk method [21, 22]. A total of 5 Kabirajes (36-60 years) were interviewed during the surveys. Kabirajes were asked whether they know about cancer and whether they treat the cancer on a regular basis. Kabirajes were selected based on their confirmatory answer to both questions. The Kabirajes mentioned the plants with which they treated cancer and took the interviewers to spots from where they collected the plants. All interviews were conducted in the Bangla language. The plants were shown along with providing of local names and the parts used. Plant specimens were collected and dried in the field and later brought back to Dhaka for complete identification at the Bangladesh National Herbarium. Nomenclature of the identified species was documented from the plant list database [http://www.theplantlist.org/].

\section{Results}

A total of 20 plant species were obtained from the Kabirajes of the three districts surveyed. The results are summarized in Table 1. These plant species are wild and belonged to 17 families. The Acanthaceae, Cucurbitaceae, and Fabaceae family contributed two plants each; the rest of the families contributed one plant each. Whole plant as well as plant parts like leaves, barks, roots, fruits, and seeds was used for preparing medicine. Leaves constituted the major plant part used, forming $40.6 \%$ of total uses. Roots, fruits, and seeds each constituted accordingly $15.6 \%, 12.5 \%$, and $9.4 \%$ of total uses. The other plant parts (whole plant, stem, bark, flower, and tuber) mentioned constituted, respectively, 9.4 and $3.1 \%$ of total uses (Figure 2).

3.1. Types of Cancer. Among developed countries, the incidence and mortality rates for various cancers are almost the same. Lung cancer is the most common cancer among men in both developing and developed countries of the world and breast cancer is the most common cancer in women. Annually, the global death rate for cancer is estimated to be more than 6 million people and over 22 million individuals have been diagnosed with cancer worldwide [23]. Table 2 has listed the types of cancer.

\section{Discussion}

Many developing countries have intensified their efforts in documenting the ethnomedical data and scientific literature on medicinal plants. In 2000, natural product derivatives were involved in 14 of the top 35 drugs based on worldwide sales [24]. Cancer chemoprevention with phytochemical compounds is a developing plot [25]. Medicinal plants have been used for cancer treatment in many countries of the world from a prolonged period of time $[26,27]$ and the treatment or prevention is attributed to their safety, low cost, and oral bioavailability as well; natural plant derivatives claimed extensive scientific screening and clinical experiments for 


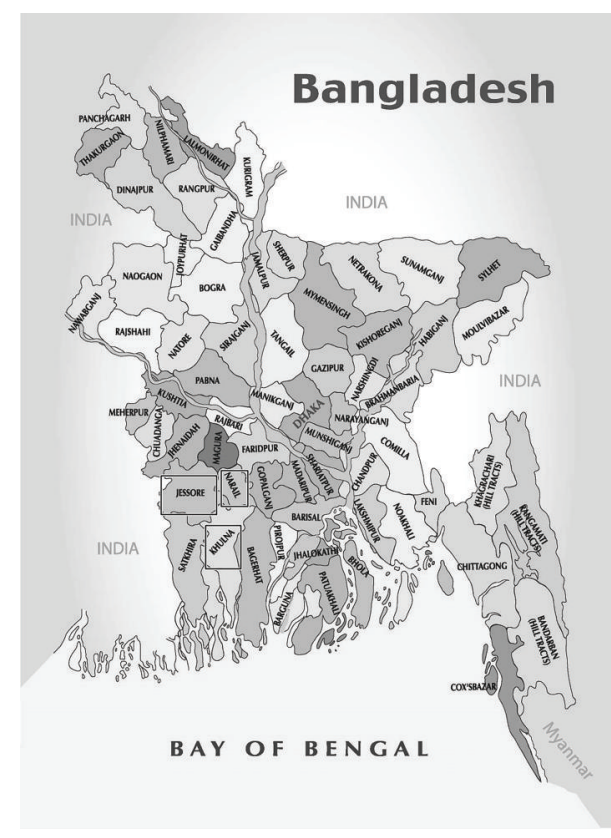

(a)

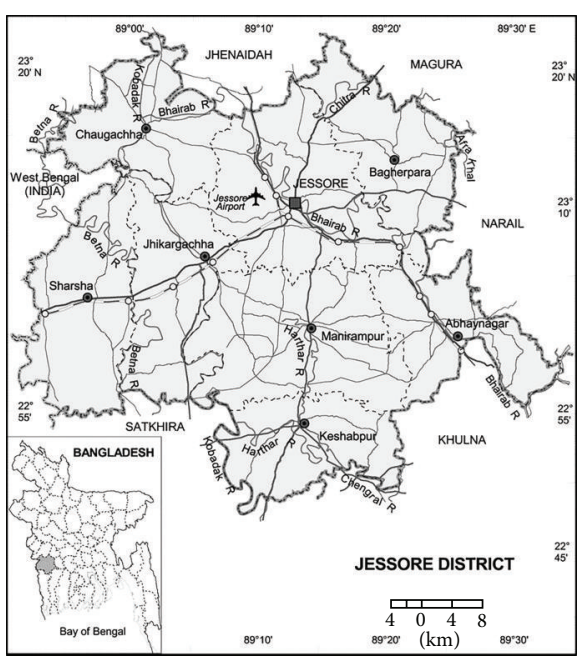

(c)

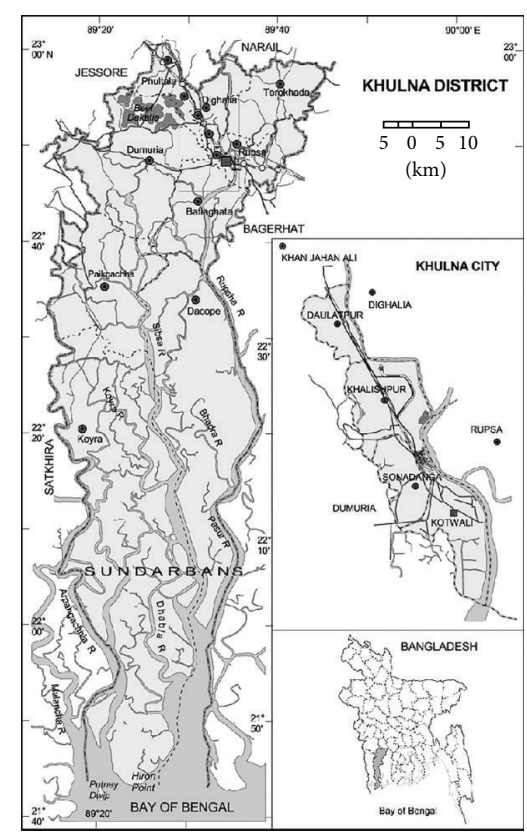

(b)

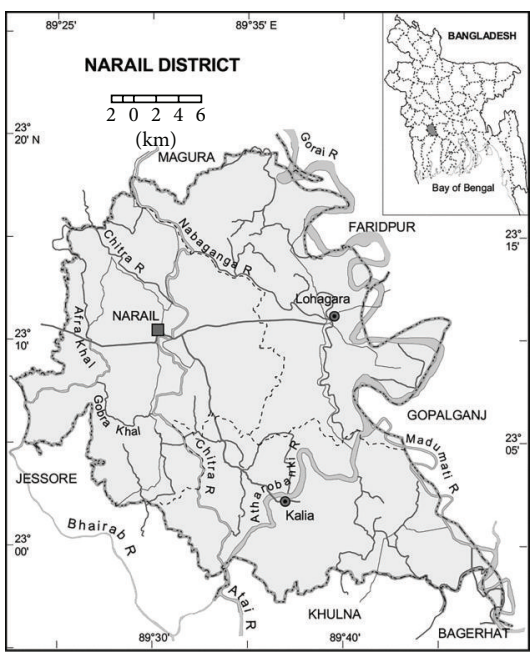

(d)

FIgure 1: (a) Map of Bangladesh showing survey area with square shade: (b) Khulna district, (c) Jessore District, and (d) Narail District.

the development of anticancer drugs [28]. Over 3000 plants species have been reported to have anticancer properties [29] and about 35000 plant samples from 20 countries have been collected and around 114,000 extracts were screened against tumor systems used as a primary screen [30]. Clinically active antineoplastic agents should be able to prolong the survival and decrease the leukocyte count of blood of tumor-bearing animals [31]. Examples of some well-known plant-derived antineoplastic lead compounds along with their specific mechanism of actions are summarized in Table 3.

4.1. Appraisement of Bangladeshi Medicinal Plants Used by the Folk Medicine Practitioners for Antineoplastic Properties. Secondary metabolites are compounds belonging to varied chemical groups that exert biological activities both on human and animal cells. Products of secondary metabolites are the main phytochemical constituents with various pharmaceutical properties serving either as protective agents against various pathogens or growth regulatory molecules. These physiological functions are the effects on cancer cells or tumor development inhibition. Plant-derived commercial anticancer drugs (vinblastine and vincristine from Catharanthus roseus) are still produced by isolation from growing plants [32]. In Table 4, we have listed some reported plantderived chemical compounds from the antineoplastic plants used by the Bangladeshi folk health practitioners in the treatment of cancer.

4.2. Abelmoschus moschatus (Musk Mallow). Hydroalcoholic seed and leaf extracts of Abelmoschus moschatus exhibited 
TABLE 1: Medicinal plants used by the folk medicine practitioners in three districts of Bangladesh for prevention and management of malignancy in cancer.

\begin{tabular}{|c|c|c|c|c|}
\hline Serial number & Botanic name & Family name & Vernacular name & Part(s) utilized \\
\hline 1 & Acanthus ilicifolius L. & Acanthaceae & Harjora & Leaf \\
\hline 2 & Hygrophila auriculata (Schumach.) Heine & Acanthaceae & Makhna & Leaf \\
\hline 3 & Borassus flabellifer L. & Arecaceae & Tal & Root, fruit \\
\hline 4 & Aristolochia indica L. & Aristolochiaceae & Ichamul & Leaf \\
\hline 5 & Emilia sonchifolia (L.) DC. ex DC. & Asteraceae & Shadhi & Whole plant \\
\hline 6 & Cannabis sativa $\mathrm{L}$. & Cannabaceae & Bhang & Leaf, root \\
\hline 7 & Blumea lacera (Burm. f.) DC. & Compositae & Kukurshunga & Leaf \\
\hline 8 & Trichosanthes kirilowii (Maxim.) Kuntze & Cucurbitaceae & Lotaakal & Whole plant \\
\hline 9 & Cucurbita maxima Duchesne & Cucurbitaceae & Kumra & Leaf, stem, and fruit \\
\hline 10 & Dillenia indica L. & Dilleniaceae & Chalta & Leaf, fruit \\
\hline 11 & Dioscorea bulbifera L. & Dioscoreaceae & Lota-bori & Root, fruit \\
\hline 12 & Erythrina variegata $\mathrm{L}$. & Fabaceae & Mandar gach & Leaf \\
\hline 13 & Sesbania sesban (L.) Merr. & Fabaceae & Dhoinche & Leaf, bark, flower, and seed \\
\hline 14 & Abelmoschus moschatus Medik. & Malvaceae & Lota koshturi & Leaf, seed \\
\hline 15 & Moringa oleifera Lam. & Moringaceae & Shajna & Leaf \\
\hline 16 & Nymphaea nouchali Burm. f. & Nymphaeaceae & Shapla & Tuber, root \\
\hline 17 & Persicaria hydropiper (L.) Delarbre & Polygonaceae & Bishalo-pata & Leaf, seed \\
\hline 18 & Murraya paniculata (L.) Jack & Rutaceae & Kamini gach & Leaf \\
\hline 19 & Veronica officinalis L. & Scrophulariaceae & Chapta-pata & Whole plant \\
\hline 20 & Clerodendrum inerme (L.) Gaertn. & Verbenaceae & Jongli jui & Root \\
\hline
\end{tabular}

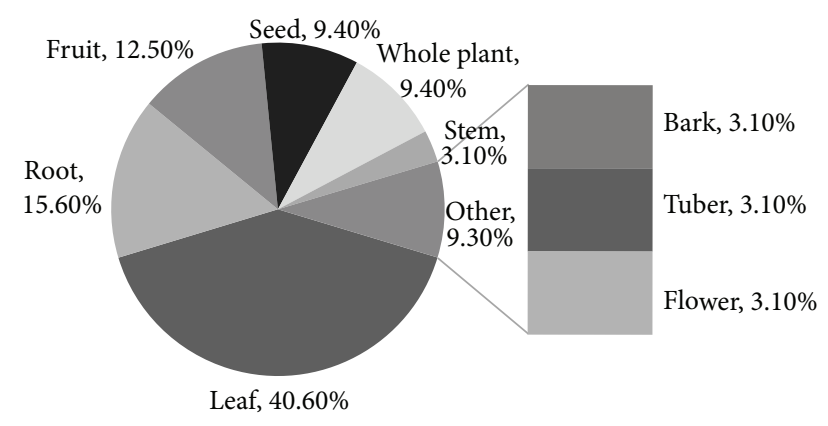

FIGURE 2: Percentage of plant parts used by the traditional medicine practitioners in the prevention and management of cancer.

antiproliferative activity against colorectal adenocarcinoma and retinoblastoma human cancer cell lines [33].

4.3. Acanthus ilicifolius (Holly Mangrove). The ethanol leaves' extract of the plant was found [34] to be cytotoxic towards lung fibroblast cells in MTT assay. Another study [35] reported that the plant extract has been shown to prevent DNA alterations in a transplantable Ehrlich Ascites carcinoma-bearing murine model and in enlargement of the survival of the animals against the proliferation of ascites tumor. Ethyl acetate extract of the whole plant of A. ilicifolius has a potential cytotoxic activity on HeLa cell and KB cell lines by comet assay [36]. Active compounds of $A$. ilicifolius flower play a role in killing Artemia salina nauplii and can
TABLE 2: List of cancer types [23].

\begin{tabular}{ll}
\hline Lung cancer & Breast cancer \\
\hline Colorectal cancer & Liver cancer \\
\hline Pancreatic cancer & $\begin{array}{l}\text { Cancers of the female reproductive tract } \\
\text { (cervical cancer, endometrial cancer, } \\
\text { and ovarian cancer) }\end{array}$ \\
\hline Prostate cancer & Urinary bladder cancer \\
\hline Lymphoma & Leukemia \\
\hline Skin cancer & Cancer of the central nervous system \\
\hline
\end{tabular}

be considered as potential cytotoxic agents as well as future candidate for cancer therapy [37].

4.4. Aristolochia indica (Indian Birthwort). The cytotoxicity and antitumor activity of the chloroform extracts of Aristolochia indica were assessed in human breast cancer cell line by MTT assay using taxol as standard and showed pronounced anticancer activity against Ehrlich Ascites Carcinoma cell line $[38,39]$. Aristoloside compound was reported to inhibit carcinogenesis [40]. Aristolochic acid was reported to possess various biological activities including antiadenocarcinoma, antineoplastic [41], and antitumor activities [42].

4.5. Borassus flabellifer (Asian Palmyra Palm). Dammarane triterpenoid 1, isolated from Borassus flabellifer seed coat, inhibits tumor necrosis factor- $\alpha$ and showed good antiproliferative activity against pancreatic cancer cell line. Apoptosis 
TABLE 3: List of some plant-derived antineoplastic lead compounds currently in use and currently in clinical trials [81, 82].

\begin{tabular}{|c|c|c|}
\hline & Source of plant & Specific mechanism of actions of the lead compounds \\
\hline \multicolumn{3}{|c|}{$\begin{array}{l}\text { Antineoplastic lead compounds currently } \\
\text { in use }\end{array}$} \\
\hline Vinblastine, Vincristine & Catharanthus roseus & $\begin{array}{l}\text { Bind to the microtubulin site in the } \beta \text {-subunit and disrupt the } \\
\text { assembly of microtubules in mitosis [83] }\end{array}$ \\
\hline Taxol & Taxus brevifolia & $\begin{array}{l}\text { Binds to the taxane site as a microtubule stabilizer and interfering } \\
\text { with the normal breakdown of microtubules during cell division } \\
{[84]}\end{array}$ \\
\hline Etoposide & Podophyllum peltatum & $\begin{array}{l}\text { Binds to tubulin and interferes with the formation of spindles in } \\
\text { mitosis [85] }\end{array}$ \\
\hline $\begin{array}{l}\text { Camptothecin, irinotecan, and } \\
\text { topotecan }\end{array}$ & Camptotheca acuminata & $\begin{array}{l}\text { Arrest the cell cycle at the S-phase by inhibiting the activity of } \\
\text { topoisomerase I, leading to the inhibition of DNA replication and } \\
\text { transcription }[86,87]\end{array}$ \\
\hline \multicolumn{3}{|c|}{$\begin{array}{l}\text { Antineoplastic lead compounds currently } \\
\text { in clinical trials }\end{array}$} \\
\hline Homoharringtonine & $\begin{array}{l}\text { Harringtonia } \\
\text { cephalotaxus }\end{array}$ & $\begin{array}{l}\text { Inhibits protein synthesis and blocking cell-cycle progression [88], } \\
\text { promotes apoptosis, and inhibits protein synthesis at the ribosomal } \\
\text { level }[89,90]\end{array}$ \\
\hline Curcumin & Curcuma longa & $\begin{array}{l}\text { Induces apoptosis and inhibits the proliferation of a variety of } \\
\text { malignant cells and is involved in the regulation of combined } \\
\text { signaling pathways at multiple levels by acting on various targets } \\
\text { including modulation of gene transcription factors (NF } \kappa \mathrm{B}, \mathrm{p} 53 \text {, } \\
\text { and AP-1), growth factors and their receptors (PDGF, EGF, and } \\
\text { VEGF), cell surface adhesion molecules (E-cadherin, } \beta \text {-cadenin), } \\
\text { and protein kinases (CDKs, EGFR, PKC, and p38 MAPK) }[91,92]\end{array}$ \\
\hline Resveratrol & $\begin{array}{l}\text { Vitis vinifera, Morus } \\
\text { alba, and Arachis } \\
\text { hypogaea }\end{array}$ & $\begin{array}{l}\text { Inhibits the growth of cancer cells and induces apoptosis by acting } \\
\text { at multiple cellular targets, including activation of p53, inhibiting } \\
10 \text { otulins, } 10 \text { genases, and cytochrome P450 enzymes, and } \\
\text { activating AMP-activated kinase (AMPK) [93-95] }\end{array}$ \\
\hline Flavopiridol & Amoora rohituka & $\begin{array}{l}\text { Exhibits apoptosis induction [96], inhibits the activity of } \\
\text { cyclin-dependent kinases (CDKs) by competing with ATP at their } \\
\text { nucleotide binding sites, and causes cell cycle arrest at either the G1 } \\
\text { or G1/M phases [97] }\end{array}$ \\
\hline
\end{tabular}

inducing activity was confirmed based on increased subG0 phase cell population in cell cycle analysis, loss of mitochondrial membrane potential, elevated levels of cytochrome c, nuclear morphological changes, and DNA fragmentation in MIA PaCa-2 pancreatic cancer cells [43]. B. flabellifer seed coat extracts were screened in another study [44] for their possible anticancer activity on growth of the HeLa cells and these preliminary studies indicated that even the lower concentrations of plant extract showed significant antiproliferative activity.

4.6. Blumea lacera (Blumea). There is an in vitro study [45] that showed that Blumea lacera exhibited broad spectrum antileukemic activity against K562, L1210, P3HR1, and U937 leukemia cells. Methanolic extract of $B$. lacera leaves has also showed cytotoxic activity against human gastric adenocarcinoma cell line, human colorectal adenocarcinoma cell line, and human breast ductal carcinoma cell line [46].

4.7. Cannabis sativa (Hemp). The interest in anticarcinogenic properties of cannabinoids was renewed after the discovery of the endocannabinoid system [47]. The administration of $\Delta 9$ THC, $\Delta 8$-THC, and cannabinol inhibited the growth of Lewis lung adenocarcinoma cells in vitro as well as in vivo after oral administration in mice [48]. Antitumorigenic mechanisms of cannabinoids are showing their ability to interfere with tumor neovascularization, cancer cell migration, adhesion, invasion, and metastasis [49]. The mechanism of cannabinoids' anticancer action depends on the ability of their agents to stimulate autophagy-mediated apoptotic cancer cell death; thus, cannabinoid action helps in cancer cell death, impairs tumor angiogenesis, and blocks invasion and metastasis [50] and cannabinoids are currently also being tested as anticancer agents in phase I/II clinical studies [51].

4.8. Cucurbita maxima (Pumpkin). Methanol extract of Cucurbita maxima aerial parts has been performed against Ehrlich Ascites Carcinoma model in mice by Saha et al. [52] for the antitumor activity and the results revealed that C. maxima possesses significant anticancer activity which may be due to its cytotoxicity and antioxidant properties. Lasparaginase is an antineoplastic agent, identified from fruit of C. maxima, used for treatment of a type of cancer that is acute lymphoblastic leukemia and non-Hodgkin's lymphoma [53] as well as being experimentally used as an anticancer agent in human patients $[54,55]$. 


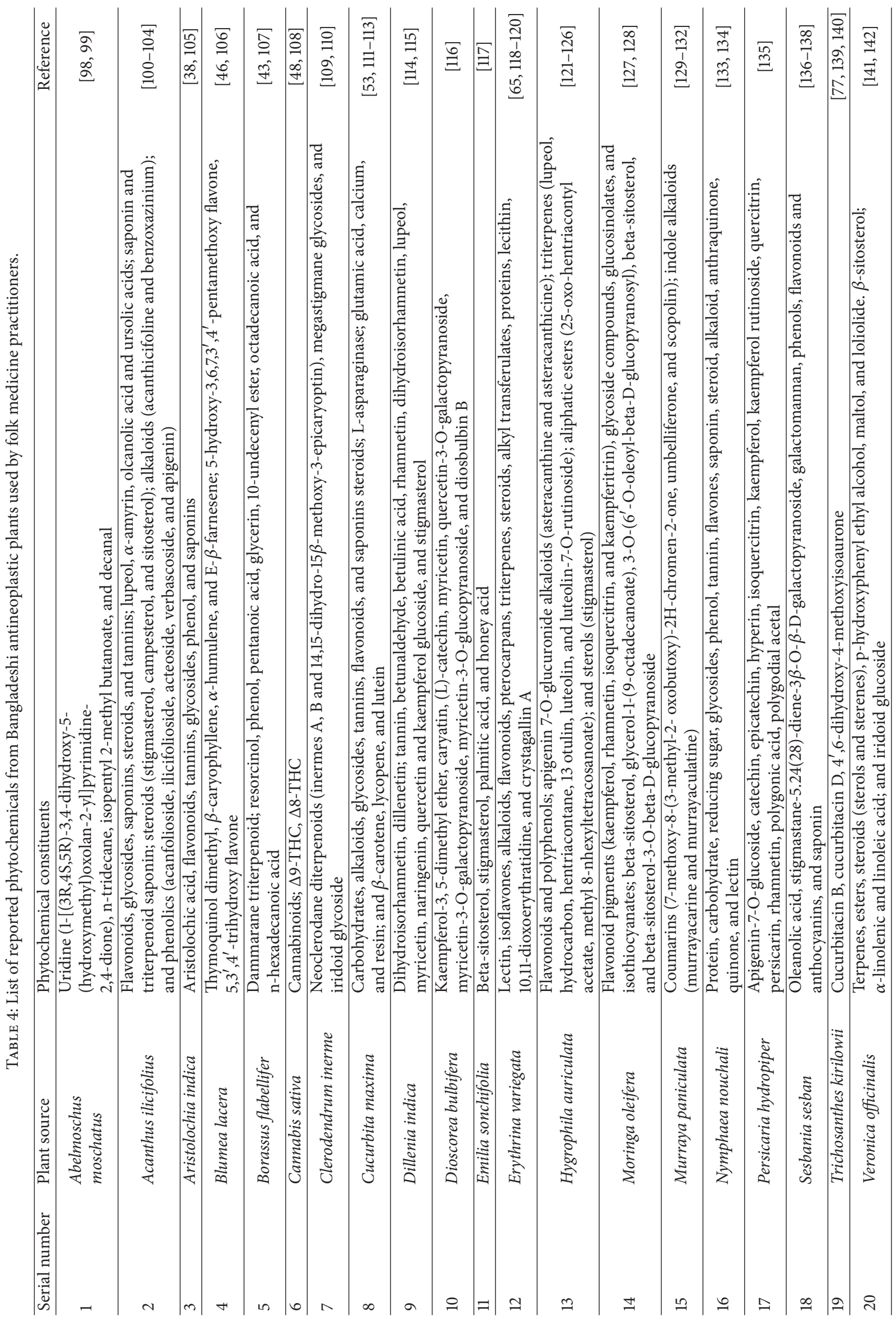


4.9. Dillenia indica (Elephant Apple). Leaf powder of Dillenia indica is given in treatment of breast cancer [56]. The methanolic extract of $D$. indica has been found to have significant antileukemic activity in human leukemic cell lines U937, HL60, and K562 [57]. Methanolic extracts of betulinic acid were prepared from the $D$. indica fruits inducing apoptosis in HT-29 cells via mitochondrial dependent pathway and proving to be a potential therapeutic agent for colon cancer [58].

4.10. Dioscorea bulbifera (Air Potato). Petroleum ether fraction of the plant showed potential effects against HepA with microstructure abnormality of HepA cells surface [59]. Immune system modulation might be related to antitumor effects of D. bulbifera rhizome, as reported in S180 and H22 tumor cells bearing mice [60].

4.11. Emilia sonchifolia (Lilac Tasselflower). The aqueous and methanolic extracts of the leaves of Emilia sonchifolia gradually exhibit antitumor activities [61]. The n-hexane extract of E. sonchifolia has anticancer effect and is rich in terpenoids [62] and terpenoids were evaluated for their potential antineoplastic activity in various human cancer cell lines such as gastric, pancreatic, and colon carcinomas [63].

4.12. Erythrina variegata (Tiger's Claw). Steroid derived from the stem bark and the leaves of Erythrina variegata showed anticancer activity against in vitro breast cancer cell T47D [64]. Alkaloids (10,11-dioxoerythratidine and crystagallin A) extracted from the leaves and stem bark of $E$. variegata plant strongly stated in vitro anticancer activity against breast cancer T47D cell lines in vitro using the Sulforhodamine B (SRB) assay [65].

4.13. Hygrophila auriculata (Marsh Barbel). The effect of $H$. auriculata on carbohydrate metabolizing enzymes in $\mathrm{N}$ nitrosodiethylamine induced hepatocellular carcinoma in rats [66]. The aqueous seed extract from $H$. auriculata displayed selective cancer cell cytotoxicity with an IC50 value of $0.22 \mathrm{mg} \mathrm{mL}^{-1}$ against colon cancer cells [67]. In vitro study of $H$. auriculata extracts has reported antitumor and $\mathrm{NF} \kappa \mathrm{B}$ inhibition [68]. Ahmad et al. reported antitumor activity from plant extract against chemically induced hepatocarcinogenesis in Wister rats [69].

4.14. Moringa oleifera (Drumstick Tree). A hydroalcoholic extract of Moringa oleifera study revealed possible chemopreventive potential against chemical carcinogenesis [70]. Different leaf extracts of $M$. oleifera produced significant cytotoxic effects on human multiple myeloma cultured cell lines [71]. A study [72] showed that leaves extract of $M$. oleifera can significantly obstruct the growth of cultured human pancreatic carcinoma cells by inhibiting the NF- $\kappa \mathrm{B}$ signaling pathway. Most of the anticancer studies of $M$. oleifera have not focused on the molecular basis of the tumor-suppressive activity but strongly suggested that it could potentially be a supreme anticancer candidate specific to cancer cells $[73,74]$.
4.15. Nymphaea nouchali (Blue Water Lily). The methanolic extract of Nymphaea nouchali roots has showed inhibitory activity towards tumor promoter in the Raji cells [75].

4.16. Persicaria hydropiper (Water Pepper). In vitro antiproliferative activity of Polygonum hydropiper (synonymy) extracts was evaluated against cervix epithelial adenocarcinoma, skin epidermoid carcinoma, and breast epithelial adenocarcinoma cells and the results confirmed substantial cell growth inhibitory activity against one or more cell lines [76].

4.17. Trichosanthes kirilowii (Chinese Cucumber). A triterpenoid compound named cucurbitacin B isolated from Trichosanthes kirilowii showed the potent inhibitory activity against HIF-1 activation induced by hypoxia in various human cancer cell lines. In vivo studies confirmed the inhibitory effect of cucurbitacin B on the expression of HIF-1 $\alpha$ proteins, leading to a decrease growth of HeLa cells in a xenograft tumor model [77]. Cucurbitacin D isolated from the plant has also been shown to suppress proliferation of HT29 human colon cancer cells [78] and the compound could be potent therapeutic agent for breast cancer by blocking tumor cell proliferation and inducing apoptosis through suppression of STAT3 activity [79] and it could also induce apoptosis in human hepatocellular carcinoma cells [80].

\section{Conclusions}

Among twenty plant species, four of the species used by folk medicine practitioners have no strong published data regarding anticancer or cytotoxic activities. These 4 species are C. inerme, M. paniculata, S. sesban, and V. officinalis. From just a brief survey of the literature, it appears that the rest of the sixteen plants used by the Kabirajes in three districts of Bangladesh present considerable potential in the treatment of cancer. Further scientific studies need to be conducted on these plants towards discovery of lead compounds, which can lead to formulation of new drugs for the prevention and management of malignant neoplastic diseases with giving less or no side effects.

\section{Conflict of Interests}

The authors declare they have no competing interests.

\section{Acknowledgment}

The authors wish to thank all the medicine practitioners for providing useful information regarding cancer treatment.

\section{References}

[1] B. Vogelstein and K. W. Kinzler, The Genetic Basis of Human Cancer, McGraw-Hill, New York, NY, USA, 2nd edition, 2002.

[2] W. Schulz, Molecular Biology of Human Cancers: An Advanced Student's Textbook, Springer, Dordrecht, The Netherlands, 2007.

[3] B. R. Zetter, "Angiogenesis and tumor metastasis," Annual Review of Medicine, vol. 49, pp. 407-424, 1998. 
[4] J. Folkman, "Role of angiogenesis in tumor growth and metastasis," Seminars in Oncology, vol. 29, no. 6, supplement 16, pp. 15-18, 2002.

[5] A. Jemal, T. Murray, E. Ward et al., "Cancer statistics, 2005," CA Cancer Journal for Clinicians, vol. 55, no. 1, pp. 10-30, 2005.

[6] P. A. Wingo, C. J. Cardinez, S. H. Landis et al., "Long-term trends in cancer mortality in the United States, 1930-1998," Cancer, vol. 97, no. 12, pp. 3133-3275, 2003.

[7] Cancer Registry Report 2005-2007, National Institute of Cancer Research and Hospital, Dhaka, Bangladesh, December 2009.

[8] A. K. Uddin, Z. J. Khan, J. Islam, and A. M. Mahmud, "Cancer care scenario in Bangladesh South Asian," Journal of Cancer, vol. 2, no. 2, pp. 102-104, 2013.

[9] V. Noronha, U. Tsomo, A. Jamshed et al., "A fresh look at oncology facts on south central Asia and SAARC countries," South Asian Journal of Cancer, vol. 1, no. 1, pp. 1-4, 2012.

[10] C. M. Cotton, Ethnobotany: Principle ad Application, John Wiley \& Sons, New York, NY, USA, 1996.

[11] M. N. Ahmed and M. N. K. Azam, “Traditional knowledge and formulations of medicinal plants used by the traditional medical practitioners of Bangladesh to treat schizophrenia like psychosis," Schizophrenia Research and Treatment, vol. 2014, Article ID 679210, 10 pages, 2014.

[12] M. N. K. Azam, MA. Mannan, and M. N. Ahmed, "Medicinal plants used by the traditional medical practitioners of Barendra and Shamatat. (Rajshahi \& Khulna Division) region in Bangladesh for treatment of cardiovascular disorders," Journal of Medicinal Plants Studies, vol. 2, no. 2, pp. 9-14, 2014.

[13] M. N. K. Azam, S. Biswas, and M. N. Ahmed, "A crosssectional study of ethnopharmacology in the Noakhali district of Bangladesh and exploring potential ocular immunostimulatory activity of the medicinal plants for the treatment of eye infections," PharmacologyOnline, vol. 1, no. 1, pp. 77-89, 2015.

[14] M. N. Hasan, M. N. K. Azam, M. N. Ahmed, and A. Hirashima, "A randomized ethnomedicinal survey of snakebite treatment in southwestern parts of Bangladesh," Journal of Traditional and Complementary Medicine, 2015.

[15] M. F. Kadir, M. S. Bin Sayeed, T. Shams, and M. M. K. Mia, "Ethnobotanical survey of medicinal plants used by Bangladeshi traditional health practitioners in the management of diabetes mellitus," Journal of Ethnopharmacology, vol. 144, no. 3, pp. 605611, 2012.

[16] M. F. Kadir, M. S. Bin Sayeed, and M. M. K. Mia, "Ethnopharmacological survey of medicinal plants used by traditional healers in Bangladesh for gastrointestinal disorders," Journal of Ethnopharmacology, vol. 147, no. 1, pp. 148-156, 2013.

[17] A. Mollik, T. Islam, A. Khatun, D. Nasrin, R. Jahan, and M. Rahmatullah, "Medicinal plants used against gastrointestinal tract disorders by traditional medicinal practitioners of Bangladesh," Planta Medica, vol. 75, article PD57, 2009.

[18] M. A. H. Mollik, M. R. Faruque, K. Akter, M. T. Islam, M. F. Hossain, and D. Sen, "Ethnomedicinal survey of medicinal plants used as remedy for HIV/AIDS related infections by the traditional medicinal practitioners of Bangladesh," in Proceedings of the 18th International AIDS Conference (AIDS '10), Abstract no. MOPE0213, Vienna, Austria, July 2010.

[19] M. Rahmatullah, R. Jahan, A. K. Azad et al., "A randomized survey of medicinal plants used by folk medicinal practitioners in six districts of bangladesh to treat rheumatoid arthritis," Advances in Natural and Applied Sciences, vol. 4, no. 2, pp. 124127, 2010.
[20] M. H. Rashid, R. Tanzin, K. C. Ghosh, R. Jahan, M. A. Khaun, and M. Rahmatullah, "An ethnoveterinary survey of medicinal plants used to treat cattle diseases in Birishiri area, Netrakona district, Bangladesh," Advances in Natural and Applied Sciences, vol. 4, no. 1, pp. 10-13, 2010.

[21] P. Maundu, "Methodology for collecting and sharing indigenous knowledge: a case study," Indigenous Knowledge and Development Monitor, vol. 3, pp. 3-5, 1995.

[22] M. N. Alexiades, "Collecting ethnobotanical data," in Selecting Guidelines for Ethnobotanical Research, pp. 53-94, The New York Botanical Garden Press, 1996.

[23] D. M. Parkin, F. Bray, J. Ferlay, and P. Pisani, "Global cancer statistics, 2002," CA: A Cancer Journal for Clinicians, vol. 55, no. 2, pp. 74-108, 2005.

[24] M. S. Butler, "The role of natural product chemistry in drug discovery," Journal of Natural Products, vol. 67, no. 12, pp. 21412153, 2004.

[25] H. Wang, T. O. Khor, L. Shu et al., "Plants vs. cancer: a review on natural phytochemicals in preventing and treating cancers and their druggability," Anti-Cancer Agents in Medicinal Chemistry, vol. 12, no. 10, pp. 1281-1305, 2012.

[26] J. L. Hartwell, Plants Used against Cancer. A Survey, Quarterman Publications, Lawrence, Mass, USA, 1982.

[27] R. Gerson-Cwillich, A. Serrano-Olvera, and A. VillalobosPrieto, "Complementary and alternative medicine (CAM) in Mexican patients with cancer," Clinical and Translational Oncology, vol. 8, no. 3, pp. 200-207, 2006.

[28] H. Raina, G. Soni, N. Jauhari, N. Sharma, and N. Bharadvaja, "Phytochemical importance of medicinal plants as potential sources of anticancer agents," Turkish Journal of Botany, vol. 38, pp. 1027-1035, 2014.

[29] J. G. Graham, M. L. Quinn, D. S. Fabricant, and N. R. Farnsworth, "Plants used against cancer-an extension of the work of Jonathan Hartwell," Journal of Ethnopharmacology, vol. 73, no. 3, pp. 347-377, 2000.

[30] S. Mohammad, "Anti-cancer agents from medicinal plants," Bangladesh journal of Pharmacology, vol. 1, no. 2, pp. 35-41, 2006.

[31] S. Kundusen, A. Bala, B. Kar et al., "Antitumor potential of Citrus limetta fruit peel in Ehrlich ascites carcinoma bearing Swiss albino mice," Alternative Medicine Studies, vol. 2, no. 1, pp. 48-51, 2012.

[32] E. K. Spiridon and G. B. Maria, Plants That Fight Cancer, CRC Press, 2004.

[33] M. Z. Gul, L. M. Bhakshu, F. Ahmad, A. K. Kondapi, I. A. Qureshi, and I. A. Ghazi, "Evaluation of Abelmoschus moschatus extracts for antioxidant, free radical scavenging, antimicrobial and antiproliferative activities using in vitro assays," $B M C$ Complementary and Alternative Medicine, vol. 11, article 64, 2011.

[34] B. H. Babu, B. S. Shylesh, and J. Padikkala, "Tumour reducing and anticarcinogenic activity of Acanthus ilicifolius in mice," Journal of Ethnopharmacology, vol. 79, no. 1, pp. 27-33, 2002.

[35] T. Chakraborty, D. Bhuniya, M. Chatterjee et al., "Acanthus ilicifolius plant extract prevents DNA alterations in a transplantable Ehrlich ascites carcinoma-bearing murine model," World Journal of Gastroenterology, vol. 13, no. 48, pp. 6538-6548, 2007.

[36] P. V. Khajure and J. L. Rathod, "Potential anticancer activity of Acanthus ilicifolius extracted from the Mangroves Forest of Karwar, West Cost of India," World Journal of Science and Technology, vol. 1, pp. 1-6, 2011. 
[37] M. Firdaus, A. A. Prihanto, and R. Nurdiani, "Antioxidant and cytotoxic activity of Acanthus ilicifolius flower," Asian Pacific Journal of Tropical Biomedicine, vol. 3, no. 1, pp. 17-21, 2013.

[38] V. Subramaniyan, R. Saravanan, D. Baskaran, and S. Ramalalingam, "In vitro free radical scavenging and anticancer potential of Aristolochia indica L. against MCF-7 cell line," International Journal of Pharmacy and Pharmaceutical Sciences, vol. 7, no. 6, pp. 392-396, 2015.

[39] A. Y. K. M. Rana and J. A. Khanam, "Aristolochia indica whole plant extract as an Antineoplastic agent," Journal of Medical Sciences, vol. 2, no. 4, pp. 2002-2205, 2002.

[40] H. Nagasawa, G. Wu, and H. Inatomi, "Effects of aristoloside, a component of guan-mu-tong (Caulis aristolochiae manshuriensis), on normal and preneoplastic mammary gland growth in mice," Anticancer Research, vol. 17, no. 1, pp. 237-240, 1997.

[41] P. Garodia, H. Ichikawa, N. Malani, G. Sethi, and B. B. Aggarwal, "From ancient medicine to modern medicine: ayurvedic concepts of health and their role in inflammation and cancer," Journal of the Society for Integrative Oncology, vol. 5, no. 1, pp. 25-37, 2007.

[42] B. Achari, S. Crakrabarty, and S. C. Pakrashi, "An N-glycoside and steroids from Aristolochia indica," Phytochemistry, vol. 20, no. 6, pp. 1444-1445, 1981.

[43] N. S. Yarla, R. Azad, M. Basha et al., "5-lipoxygenase and cyclooxygenase inhibitory dammarane triterpenoid 1 from borassus flabellifer seed coat inhibits tumor necrosis factor- $\alpha$ secretion in LPSInduced THP-1 human monocytes and induces apoptosis in MIA PaCa-2 pancreatic cancer cells," Anti-Cancer Agents in Medicinal Chemistry, vol. 15, no. 8, pp. 1066-1077, 2015.

[44] G. R. Duddukuri, Y. N. Sastry, D. S. V.G. K. Kaladhar, P. A. Babu, K. K. Rao, and K. K. Chaitanya, "Preliminary studies on in vitro anti-tumor activity of tender seed coat extract of Borassus flabellifer L. on hela cell line," International Journal of Current Research, vol. 3, no. 7, pp. 75-77, 2011.

[45] L.-C. Chiang, H.-Y. Cheng, C.-C. Chen, and C.-C. Lin, "In vitro anti-leukemic and antiviral activities of traditionally used medicinal plants in Taiwan," The American Journal of Chinese Medicine, vol. 32, no. 5, pp. 695-704, 2004.

[46] P. Tiwari, G. Aluja, A. S. Pandey, and N. Sharma, "Isolation and biological evaluation of some phytoconstituents from Blumea lacera (Burn F.) D.C," International Journal of Pharmacy \& Pharmaceutical Sciences, vol. 4, supplement 4, pp. 148-150, 2012.

[47] P. Massi, M. Solinas, V. Cinquina, and D. Parolaro, "Cannabidiol as potential anticancer drug," British Journal of Clinical Pharmacology, vol. 75, no. 2, pp. 303-312, 2013.

[48] A. E. Munson, L. S. Harris, M. A. Friedman, W. L. Dewey, and R. A. Carchman, "Antineoplastic activity of cannabinoids," Journal of the National Cancer Institute, vol. 55, no. 3, pp. 597-602, 1975.

[49] N. Freimuth, R. Ramer, and B. Hinz, "Antitumorigenic effects of cannabinoids beyond apoptosis," Journal of Pharmacology and Experimental Therapeutics, vol. 332, no. 2, pp. 336-344, 2010.

[50] G. Velasco, C. Sánchez, and M. Guzmán, "Towards the use of cannabinoids as antitumour agents," Nature Reviews Cancer, vol. 12, no. 6, pp. 436-444, 2012.

[51] G. Velasco, S. Hernández-Tiedra, D. Dávila, and M. Lorente, "The use of cannabinoids as anticancer agents," Progress in Neuro-Psychopharmacology and Biological Psychiatry, vol. 64, pp. 259-266, 2016.

[52] P. Saha, U. K. Mazumder, P. K. Haldar et al., "Anticancer activity of methanol extract of Cucurbita maxima against
Ehrlich as-cites carcinoma," International Journal of Research in Pharmaceutical Sciences, vol. 2, no. 1, pp. 52-59, 2011.

[53] A. Shrivastava, A. A. Khan, S. K. Jain et al., "Biotechnological advancement in isolation of anti-neoplastic compounds from natural origin: a novel source of L-asparaginase," Acta Biomedica, vol. 81, no. 2, pp. 104-108, 2010.

[54] L. A. Clavell, R. D. Gelber, H. J. Cohen et al., "Four agent induction and intensive asparaginase therapy for treatment of childhood acute lymphoblastic leukemia," The New England Journal of Medicine, vol. 315, no. 11, pp. 657-663, 1986.

[55] M. D. Story, D. W. Voehringer, L. C. Stephens, and R. E. Meyn, "L-asparaginase kills lymphoma cells by apoptosis," Cancer Chemotherapy and Pharmacology, vol. 32, no. 2, pp. 129-133, 1993.

[56] M. Anisuzzaman, A. H. M. M. Rahman, M. Harun-Or-Rashid, A. T. M. Naderuzzaman, and A. K. M. R. Islam, "An ethnobotanical study of madhupur, Tangail," Journal of Applied Polymer Science, vol. 3, no. 7, pp. 519-530, 2007.

[57] D. Kumar, S. Mallick, J. R. Vedasiromoni, and B. C. Pal, "Anti-leukemic activity of Dillenia indica L. fruit extract and quantification of betulinic acid by HPLC," Phytomedicine, vol. 17, no. 6, pp. 431-435, 2010.

[58] D. Dutta, A. Sarkar, B. Chakraborty, C. Chowdhury, and P. Das, "Induction of apoptosis by a potent Betulinic acid derivative in Human colon carcinoma HT-29 cells," International Journal of Scientific and Research Publications, vol. 5, no. 2, pp. 1-7, 2015.

[59] Z.-L. Yu, X.-R. Liu, M. McCulloch, and J. Gao, "Anticancer effects of various fractions extracted from Dioscorea bulbifera on mice bearing HepA," Zhongguo Zhong Yao Za Zhi, vol. 29, no. 6, pp. 563-567, 2004.

[60] J.-M. Wang, L.-L. Ji, C. J. Banford-White et al., "Antitumor activity of Dioscorea bulbifera L. rhizome in vivo," Fitoterapia, vol. 83, no. 2, pp. 388-394, 2012.

[61] B. S. Shylesh and J. Padikkala, "In vitro cytotoxic and antitumor property of Emilia sonchifolia (L.) DC in mice," Journal of Ethnopharmacology, vol. 73, no. 3, pp. 495-500, 2000.

[62] B. S. Shylesh, S. Ajikumaran Nair, and A. Subramoniam, "Induction of cell-specific apoptosis and protection from Dalton's lymphoma challenge in mice by an active fraction from Emilia sonchifolia," Indian Journal of Pharmacology, vol. 37, no. 4, pp. 232-237, 2005.

[63] H. Lage, N. Duarte, C. Coburger, A. Hilgeroth, and M. J. U. Ferreira, "Antitumor activity of terpenoids against classical and atypical multidrug resistant cancer cells," Phytomedicine, vol. 17, no. 6, pp. 441-448, 2010.

[64] T. Herlina, Nasrudin, U. Supratman, A. Subamas, A. Sutardjo, and H. Hayashi, "An isoflavonoid, warangalone from the stem bark of dadap ayam (Erythrina variegata)," Journal of Basic Sciences, vol. 9, no. 1, pp. 45-47, 2008.

[65] H. Tati, K. Nurlelasari Dikdik, S. Unang, and U. Zalinar, "In vitro anticancer and antimalarial Erystagallin-a from Erythrina variegata (L) stem bark," Medicinal Plants, vol. 3, no. 1, pp. 9-13, 2011.

[66] M. P. Balasubramaniam and S. Premkumari, "Effects of Hygrophila auriculata on carbohydrate metabolizing enzymes in N-nitrosodiethylamine induced hepatocellular Carcinoma in rats," Journal of Herbal Medicine, vol. 1, pp. 85-90, 2012.

[67] S. J. Uddin, I. D. Grice, and E. Tiralongo, "Cytotoxic effects of Bangladeshi medicinal plant extracts," Evidence-Based Complementary and Alternative Medicine, vol. 2011, Article ID 578092, 7 pages, 2011. 
[68] I. Lampronti, M. T. Khan, N. Bianchi et al., "Bangladeshi medicinal plant extracts inhibiting molecular interactions between nuclear factors and target DNA sequences mimicking NF- $\kappa \mathrm{B}$ binding sites," Medicinal chemistry, vol. 1, no. 4, pp. 327-333, 2005.

[69] S. Ahmed, A. Rahman, M. Mathur, M. Athar, and S. Sultana, "Anti-tumor promoting activity of Asteracantha longifolia against experimental hepatocarcinogenesis in rats," Food and Chemical Toxicology, vol. 39, no. 1, pp. 19-28, 2001.

[70] R. Bharali, J. Tabassum, and M. R. H. Azad, "Chemomodulatory effect of Moringa oleifera, lam, on hepatic carcinogen metabolising enzymes, antioxidant parameters and skin papillomagenesis in mice," Asian Pacific Journal of Cancer Prevention, vol. 4, no. 2, pp. 131-139, 2003.

[71] M. V. S. Parvathy and A. Umamaheshwari, "Cytotoxic effect of Moringa oleifera leaf extracts on human multiple myeloma cell lines," Trends in Medical Research, vol. 2, no. 1, pp. 44-50, 2007.

[72] L. Berkovich, G. Earon, I. Ron, A. Rimmon, A. Vexler, and S. Lev-Ari, "Moringa Oleifera aqueous leaf extract downregulates nuclear factor- $\kappa \mathrm{B}$ and increases cytotoxic effect of chemotherapy in pancreatic cancer cells," BMC Complementary and Alternative Medicine, vol. 13, article 212, 2013.

[73] I. L. Jung, "Soluble extract from Moringa oleifera leaves with a new anticancer activity," PLoS ONE, vol. 9, no. 4, Article ID e95492, 2014.

[74] L. V. Costa-Lotufo, M. T. H. Khan, A. Ather et al., "Studies of the anticancer potential of plants used in Bangladeshi folk medicine," Journal of Ethnopharmacology, vol. 99, no. 1, pp. 2130, 2005.

[75] A. Murakami, A. M. Ali, K. Mat-Salleh, K. Koshimizu, and H. Ohigashi, "Screening for the in vitro anti-tumor-promoting activities of edible plants from Malaysia," Bioscience, Biotechnology and Biochemistry, vol. 64, no. 1, pp. 9-16, 2000.

[76] I. Lajter, I. Zupkó, J. Molnár et al., "Antiproliferative activity of polygonaceae species from the Carpathian Basin against human cancer cell lines," Phytotherapy Research, vol. 27, no. 1, pp. 77-85, 2013.

[77] J. Ma, Y. Zi Jiang, H. Shi et al., "Cucurbitacin B inhibits the translational expression of hypoxia-inducible factor- $1 \alpha$," European Journal of Pharmacology, vol. 723, no. 1, pp. 46-54, 2014.

[78] L. Pan, Y. Yong, Y. Deng et al., "Isolation, structure elucidation, and biological evaluation of 16,23-epoxycucurbitacin constituents from eleaocarpus Chinensis," Journal of Natural Products, vol. 75, no. 3, pp. 444-452, 2012.

[79] S. R. Kim, H. S. Seo, H.-S. Choi et al., "Trichosanthes kirilowii ethanol extract and cucurbitacin D inhibit cell growth and induce apoptosis through inhibition of STAT3 activity in breast cancer cells," Evidence-Based Complementary and Alternative Medicine, vol. 2013, Article ID 975350, 9 pages, 2013.

[80] N. Takahashi, Y. Yoshida, T. Sugiura, K. Matsuno, A. Fujino, and U. Yamashita, "Cucurbitacin D isolated from Trichosanthes kirilowii induces apoptosis in human hepatocellular carcinoma cells in vitro," International Immunopharmacology, vol. 9, no. 4, pp. 508-513, 2009.

[81] D. R. A. Mans, A. B. Da Rocha, and G. Schwartsmann, "Anticancer drug discovery and development in Brazil: targeted plant collection as a rational strategy to acquire candidate anti-cancer compounds," Oncologist, vol. 5, no. 3, pp. 185-198, 2000.

[82] L. Pan, H.-B. Chai, and A. D. Kinghorn, "Discovery of new anticancer agents from higher plants," Frontiers in Bioscience, vol. 4, no. 1, pp. 142-156, 2012.
[83] M. A. Jordan and L. Wilson, "Microtubules as a target for anticancer drugs," Nature Reviews Cancer, vol. 4, no. 4, pp. 253265, 2004.

[84] D. G. I. Kingston, "Tubulin-interactive natural products as anticancer agents," Journal of Natural Products, vol. 72, no. 3, pp. 507-515, 2009.

[85] K. R. Hande, "Etoposide: four decades of development of a topoisomerase II inhibitor," European Journal of Cancer, vol. 34, no. 10, pp. 1514-1521, 1998.

[86] G. M. Cragg and D. J. Newman, "A tale of two tumor targets: topoisomerase I and tubulin. The Wall and Wani contribution to cancer chemotherapy," Journal of Natural Products, vol. 67, no. 2, pp. 232-244, 2004.

[87] Y.-H. Hsiang, M. G. Lihou, and L. F. Liu, "Arrest of replication forks by drug-stabilized topoisomerase I-DNA cleavable complexes as a mechanism of cell killing by camptothecin," Cancer Research, vol. 49, no. 18, pp. 5077-5082, 1989.

[88] D. C. Zhou, R. Zittoun, and J. P. Marie, "Homoharringtonine: an effective new natural product in cancer chemotherapy," Bulletin du Cancer, vol. 82, no. 12, pp. 987-995, 1995.

[89] H. Itokawa, X. Wang, and K.-H. Lee, "Homoharringtonine and related compounds," in Anticancer Agents from Natural Products, M. Cragg Gordon, G. Kingston David, and J. Newman David, Eds., pp. 47-70, CRC/Taylor \& Francis, Boca Raton, Fla, USA, 2005

[90] A. Quintás-Cardama, H. Kantarjian, and J. Cortes, "Homoharringtonine, omacetaxine mepesuccinate, and chronic myeloid leukemia circa 2009," Cancer, vol. 115, no. 23, pp. 5382-5393, 2009.

[91] B. B. Aggarwal, C. Sundaram, N. Malani, and H. Ichikawa, "Curcumin: the Indian solid gold," Advances in Experimental Medicine and Biology, vol. 595, pp. 1-75, 2007.

[92] G. Sa, T. Das, S. Banerjee, and J. Chakraborty, "Curcumin: from exotic spice to modern anticancer drug," Al Ameen Journal of Medical Sciences, vol. 3, no. 1, pp. 21-37, 2010.

[93] B. B. Aggarwal, A. Bhardwaj, R. S. Aggarwal, N. P. Seeram, S. Shishodia, and Y. Takada, "Role of resveratrol in prevention and therapy of cancer: preclinical and clinical studies," Anticancer Research, vol. 24, no. 5, pp. 2783-2840, 2004.

[94] M. Athar, J. H. Back, X. Tang et al., "Resveratrol: a review of preclinical studies for human cancer prevention," Toxicology and Applied Pharmacology, vol. 224, no. 3, pp. 274-283, 2007.

[95] A. Bishayee, T. Politis, and A. S. Darvesh, "Resveratrol in the chemoprevention and treatment of hepatocellular carcinoma," Cancer Treatment Reviews, vol. 36, no. 1, pp. 43-53, 2010.

[96] V. Kryštof and S. Uldrijan, "Cyclin-dependent kinase inhibitors as anticancer drugs," Current Drug Targets, vol. 11, no. 3, pp. 291302, 2010.

[97] A. M. Senderowicz, "Flavopiridol: the first cyclin-dependent kinase inhibitor in human clinical trials," Investigational New Drugs, vol. 17, no. 3, pp. 313-320, 1999.

[98] R. Li, C. Wang, T. Chen, and P. Chen, "Quantitative proteomic analysis of cold-responsive proteins in Abelmoschus moschatus," Journal of Animal \& Plant Sciences, vol. 14, no. 3, pp. 2006-2023, 2012.

[99] I. Molfetta, L. Ceccarini, M. Macchia, G. Flamini, and P. L. Cioni, "Abelmoschus esculentus (L.) Moench. and Abelmoschus moschatus Medik: seeds production and analysis of the volatile compounds," Food Chemistry, vol. 141, no. 1, pp. 34-40, 2013.

[100] M. N. Ahmed, T. Sultana, M. N. K. Azam, and M. Rahmatullah, "A preliminary antihyperglycemic and antinociceptive activity 
evaluation of a mangrove species Acanthus ilicifolius L. leaves in mice," Asian Journal of Traditional Medicines, vol. 9, no. 6, pp. 143-149, 2014.

[101] R. Wöstmann and G. Liebezeit, "Chemical composition of the mangrove holly Acanthus ilicifolius (Acanthaceae)-review and additional data," Senckenbergiana Maritima, vol. 38, no. 1, pp. 31-37, 2008.

[102] U. Kokpol, V. Chittawong, and D. H. Miles, "Chemical constituents of the roots of Acanthus illicifolius," Journal of Natural Products, vol. 49, no. 2, pp. 355-356, 1986.

[103] K. P. Tiwara, P. K. Minocha, and M. Masood, "Acanthicifolinea new alkaloid from Acanthus ilicifolius," Polish Journal of Chemistry, vol. 54, pp. 857-858, 1980.

[104] C.-H. Huo, B. Wang, W.-H. Lin, and Y.-Y. Zhao, "Benzoxazinones from Acanthus ilicifolius," Biochemical Systematics and Ecology, vol. 33, no. 6, pp. 643-645, 2005.

[105] A. Pakrashi and C. Shaha, "Effect of methyl ester of aristolic acid from Aristolochia indica Linn. on fertility of female mice," Experientia, vol. 34, no. 9, pp. 1192-1193, 1978.

[106] I. Laakso, T. Seppänen-Laakso, R. Hiltunen, and O. Ekundayo, "Composition of the essential oil of Blumea lacera DC. (Asteraceae) leaves from Nigeria," Flavour and Fragrance Journal, vol. 4, no. 2, pp. 73-75, 1989.

[107] S. Subashini, V. Rameshkannan, and P. Mani, "Phytochemical and GC-MS analysis of bioactive compounds from borassus flabellifer linn from root," European Journal of Molecular Biology and Biochemistry, vol. 2, no. 3, pp. 148-152, 2015.

[108] M. Guzmán, "Cannabinoids: potential anticancer agents," Nature Reviews Cancer, vol. 3, no. 10, pp. 745-755, 2003.

[109] R. Pandey, R. K. Verma, and M. M. Gupta, "Neo-clerodane diterpenoids from Clerodendrum inerme," Phytochemistry, vol. 66, no. 6, pp. 643-648, 2005.

[110] T. Kanchanapoom, R. Kasai, P. Chumsri, Y. Hiraga, and K. Yamasaki, "Megastigmane and iridoid glucosides from Clerodendrum inerme," Phytochemistry, vol. 58, no. 2, pp. 333-336, 2001.

[111] S. D. Dubey, "Overview on Cucurbita maxima," International Journal of Phytopharmacy, vol. 2, no. 3, pp. 68-71, 2012.

[112] K. R. Dutta, S. Banerjee, and A. Mitra, "Medicinal plants of West midnapore, India: emphasis on phytochemical containment having role on oral cancer," International Journal of Phytopharmacology, vol. 3, no. 2, pp. 198-208, 2012.

[113] A. Murakami, M. Nakashima, T. Koshiba et al., "Modifying effects of carotenoids on superoxide and nitric oxide generation from stimulated leukocytes," Cancer Letters, vol. 149, no. 1-2, pp. 115-123, 2000.

[114] S. M. Sundarapandian and P. S. Swamy, "Litter production and leaf-litter decomposition of selected tree species in tropical forests at Kodayar in the Western Ghats, India," Forest Ecology and Management, vol. 123, no. 2-3, pp. 231-244, 1999.

[115] D. Gandhi and P. Mehta, "Dillenia indica Linn. and Dillenia pentagyna Roxb.: pharmacognostic, phytochemical and therapeutic aspects," Journal of Applied Pharmaceutical Science, vol. 3, no. 11, pp. 134-142, 2013.

[116] H. Gao, M. Kuroyanagi, L. Wu, N. Kawahara, T. Yasuno, and Y. Nakamura, "Antitumor-promoting constituents from Dioscorea bulbifera L. in JB6 mouse epidermal cells," Biological and Pharmaceutical Bulletin, vol. 25, no. 9, pp. 1241-1243, 2002.

[117] J. J. Gao, D. L. Cheng, and X. P. Liu, "Chemical constituents of Emilia sonchifolia L. DC," Zhongguo Zhong Yao Za Zhi, vol. 18, no. 2, pp. 102-127, 1993.
[118] T. K. Datta and P. S. Basu, "Human erythrocyte specific lectin from the seeds of Indian coral tree, Erythrina variegata Linn, var. orientali Linn, Merrill," Journal of Biosciences, vol. 5, no. 1, pp. 25-30, 1983.

[119] L. Xiaoli, W. Naili, W. M. Sau, A. S. C. Chen, and Y. Xinsheng, "Four new isoflavonoids from the stem bark of Erythrina variegata," Chemical and Pharmaceutical Bulletin, vol. 54, no. 4, pp. 570-573, 2006.

[120] A. Kumar, S. Lingadurai, A. Jain, and N. R. Barman, "Erythrina variegata Linn: a review on morphology, phytochemistry, and pharmacological aspects," Pharmacognosy Reviews, vol. 4, no. 8, pp. 147-152, 2010.

[121] A. Ghani, Medicinal Plants of Bangladesh with Chemical Constituents and Uses, Asiatic Society of Bangladesh, Dhaka, Bangladesh, 2003.

[122] P. Bairaj and S. Nagarajan, "Apigenin 7-O-glucuronide from the flowers of Asteracantha longifolia Nees," Indian Drugs, vol. 19, pp. 150-152, 1982.

[123] V. V. Parashar and H. Singh, "Investigation of Astercantha longifolia Nees," Indian Journal of Pharmacology, vol. 27, no. 4, pp. 109-113, 1965.

[124] T. R. Govindachari, K. Nagarajan, and B. R. Pai, "Isolation of lupeol from the root of Asteracantha longifolia nees," Indian Journal of Scientific Research B, vol. 16, article 72, 1957.

[125] T. N. Misra, R. S. Singh, H. S. Pandey, B. K. Singh, and R. P. Pandey, "Constituents of Asteracantha longifolia," Fitoterapia, vol. 72, no. 2, pp. 194-196, 2001.

[126] C. Quasim and N. L. Dutta, "Reported the prescence of stigmasterol in the root of Asteracantha longifolia Nees," Journal of Indian Chemical Society, vol. 44, article 82, 1967.

[127] C. K. Bose, "Possible role of Moringa oleifera Lam. root in epithelial ovarian cancer," Medscape General Medicine, vol. 9, article 26, 2007.

[128] A. P. Guevara, C. Vargas, H. Sakurai et al., "An antitumor promoter from Moringa oleifera Lam.," Mutation Research/Genetic Toxicology and Environmental Mutagenesis, vol. 440, no. 2, pp. 181-188, 1999.

[129] Atta-ur-Rahman, M. Shabbir, S. Z. Sultani, A. Jabbar, and M. I. Choudhary, "Cinnamates and coumarins from the leaves of Murraya paniculata," Phytochemistry, vol. 44, no. 4, pp. 683685, 1997.

[130] J. K. Lin and T. S. Wu, "Constituents of flowers of Murraya paniculata," Journal of the Chinese Chemical Society, vol. 41, no. 2, pp. 213-216, 1994.

[131] T.-S. Wu, M.-J. Liou, T.-T. Jong, Y.-J. Chen, and J.-S. Lai, "Indole alkaloids and coumarins from the root bark of Murraya paniculata var. Omphalocarpa," Phytochemistry, vol. 28, no. 10, pp. 2873-2874, 1989.

[132] T.-S. Wu, Y.-Y. Chan, Y.-L. Leu, and S.-C. Huang, "A flavonoid and indole alkaloid from flowers of Murraya paniculata," Phytochemistry, vol. 37, no. 1, pp. 287-288, 1994.

[133] M. Parimala and F. G. Shoba, "Phytochemical analysis and In vitro antioxidant acitivity of hydroalcoholic seed extract of Nymphaea nouchali Burm. f.", Asian Pacific Journal of Tropical Biomedicine, vol. 3, no. 11, pp. 887-895, 2013.

[134] S. R. Kabir, M. A. Zubair, M. Nurujjaman et al., "Purification and characterization of a $\mathrm{Ca}^{2+}$-dependent novel lectin from Nymphaea nouchali tuber with antiproliferative activities," Bioscience Reports, vol. 31, no. 6, pp. 465-475, 2011.

[135] A. K. M. M. Huq, J. A. Jamal, and J. Stanslas, "Ethnobotanical, phytochemical, pharmacological, and toxicological aspects of 
Persicaria hydropiper (L.) delarbre," Evidence-Based Complementary and Alternative Medicine, vol. 2014, Article ID 782830, 11 pages, 2014.

[136] V. Vadivel, A. Patel, and H. K. Biesalski, "Effect of traditional processing methods on the antioxidant, $\alpha$-amylase and $\alpha$ glucosidase enzyme inhibition properties of Sesbania sesban Merrill seeds," CyTA-Journal of Food, vol. 10, no. 2, pp. 128136, 2012.

[137] N. Das, P. Chandran, and S. Chakraborty, "Potent spermicidal effect of oleanolic acid 3-beta-d-glucuronide, an active principle isolated from the plant Sesbania sesban Merrill," Contraception, vol. 83, no. 2, pp. 167-175, 2011.

[138] M. Kathiresh, P. D. Suganya, and M. Saravanakumar, "Bioactive compounds in Sesbania sesban flower and its antioxidant and antimicrobial activity," Journal of Pharmacy Research, vol. 5, no. 1, pp. 293-390, 2012.

[139] M. E. Barbercheck and J. Wang, "Effect of cucurbitacin D on in vitro growth of Xenorhabdus and Photorhabdus spp., symbiotic bacteria of entomopathogenic nematodes," Journal of Invertebrate Pathology, vol. 68, no. 2, pp. 141-145, 1996.

[140] C. Mi, J. Ma, H. Shi et al., “4',6-Dihydroxy-4-methoxyisoaurone inhibits the HIF- $1 \alpha$ pathway through inhibition of Akt/mTOR/ p70S6K/4E-BP1 phosphorylation," Journal of Pharmacological Sciences, vol. 125, no. 2, pp. 193-201, 2014.

[141] M. Valyova, V. Hadjimitova, S. Stoyanov, Y. Ganeva, and I. Trayko Petkov, "Free radical scavenging activity of extracts from Bulgarian Veronica officinalis L. and GC-MS analysis of ethanol extract," The Internet Journal of Aesthetic and Antiaging Medicine, vol. 2, no. 1, pp. 1-4, 2008.

[142] I. Saracoglu, F. H. Oztunca, A. Nagatsu, and U. S. Harput, "Iridoid content and biological activities of Veronica cuneifolia subsp. cuneifolia and V. cymbalaria," Pharmaceutical Biology, vol. 49, no. 11, pp. 1150-1157, 2011. 

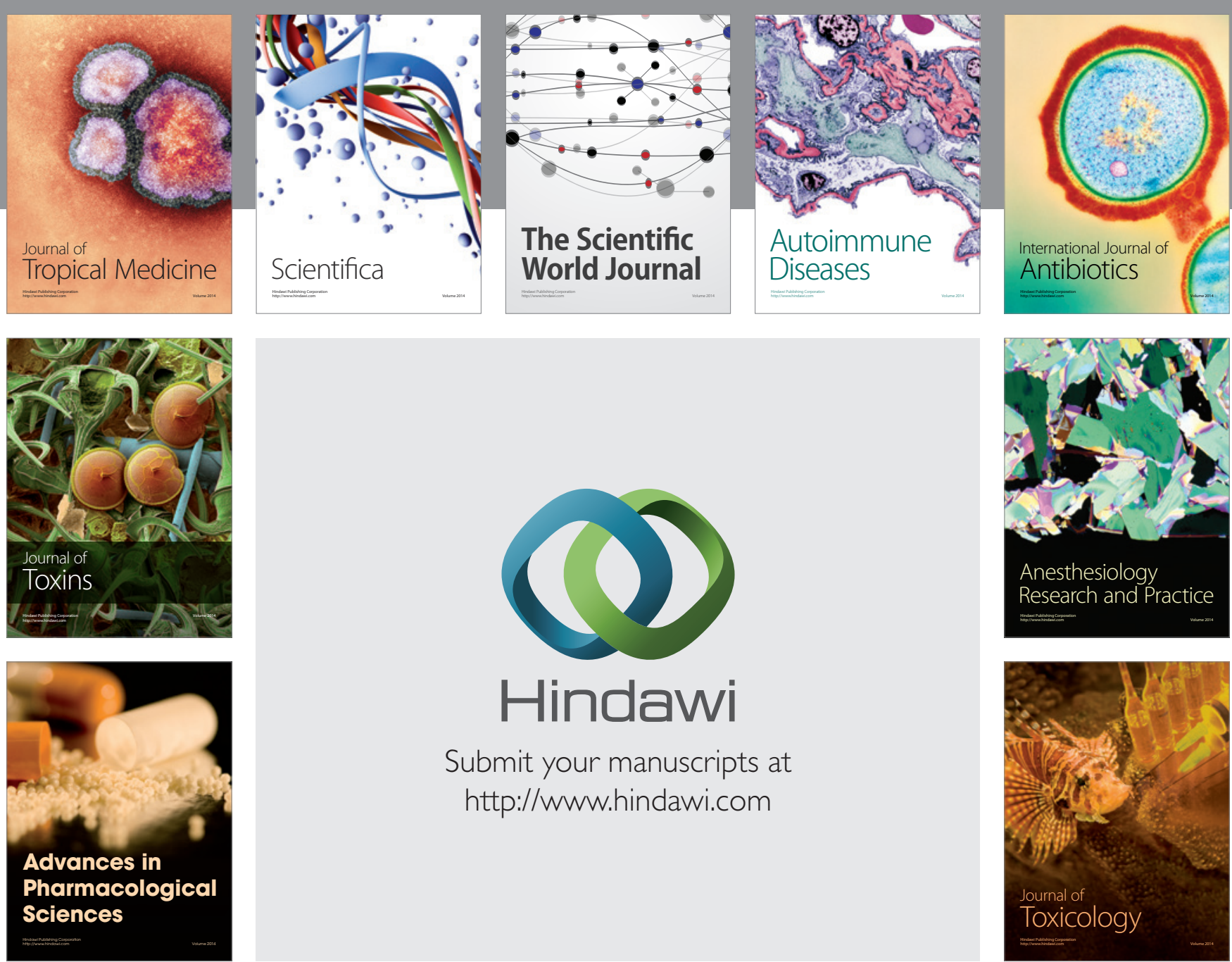

\section{Hindawi}

Submit your manuscripts at

http://www.hindawi.com
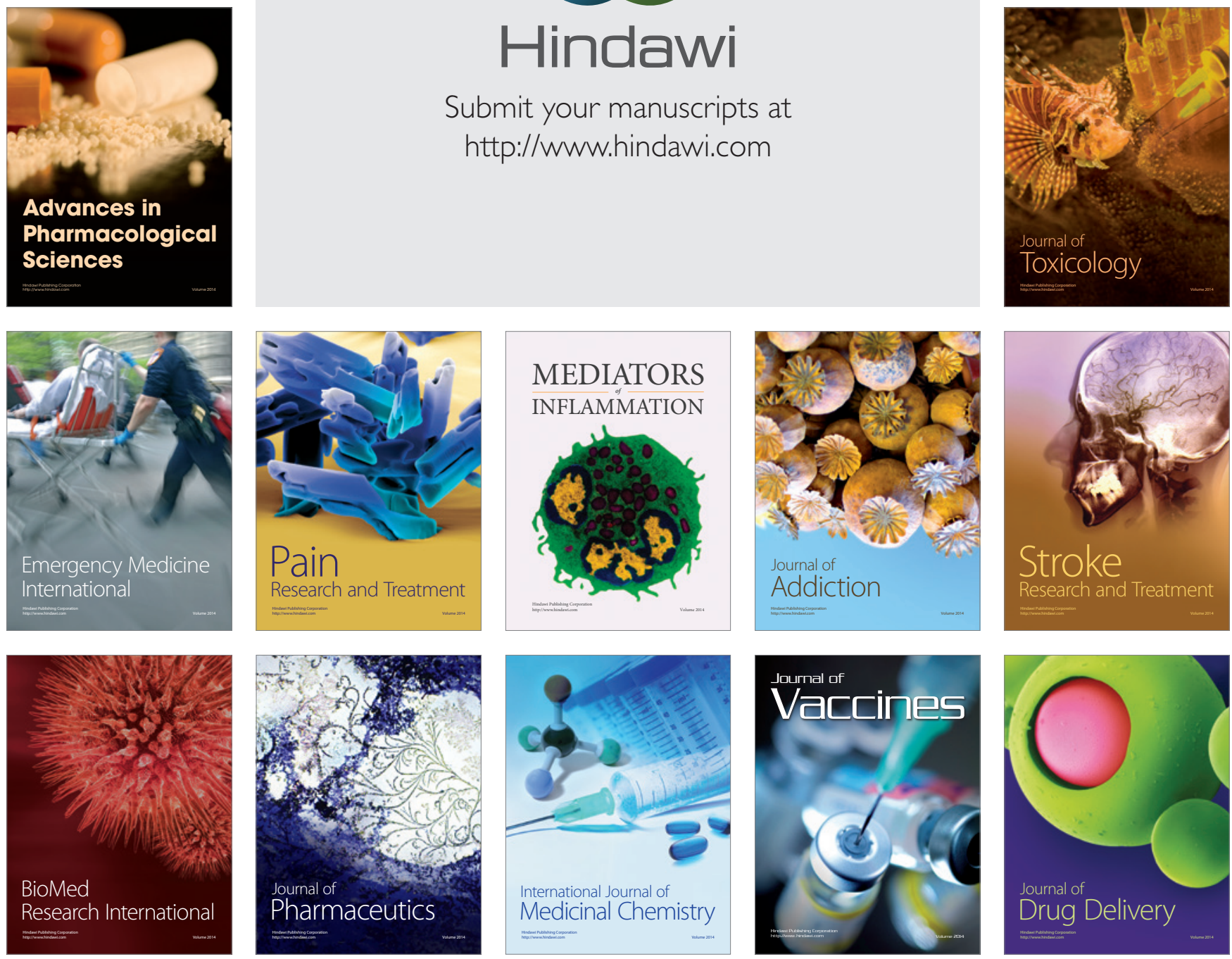